\title{
Religious Education Service For Students of Indigenous Religion of Nualu
}

\author{
Vica Jillyan Edsti Saija ${ }^{1}$, Andry Simatauw ${ }^{2}$ \\ Faculty of Law, Universitas Pattimura, Ambon, Indonesia ${ }^{1}$ \\ Social Religion Faculty, Institut Agama Kristen Negeri, Ambon, Indonesia ${ }^{2}$ \\ vicajes297@gmail.com ${ }^{1}$, andrysimatauw3008@gmail.com²
}

\begin{abstract}
This paper is focusing on Indonesian who are indigenous and still hold their original beliefs or as believers of The Almighty God. The right of education which is discussing here is the right of religious education from Nuaulu tribe students as mandated by Law Number 20 Year 2003, Regulation of Minister of Education and Culture Number 27 Year 2016. The constitutional rights are strengthened by the Constitutional Court Decision Number 97/PUU-XIV/2016 to the people who believe. This study examines whether religious education for students with the Nuaulu's religion has been proceeded according to the instructions of the legal instruments or not and what are the challenge in the implementation. The method used in this writing is empirical juridical research with the location of the research is in Central Maluku Regency. Data analysis used in this paper is qualitative analysis. With the result that religious education for the beliefs of the Nuaulu tribe has not been realized until now in accordance with the laws and regulations, and the obstacle is that elements in the management of education standards have not been fully fulfilled.
\end{abstract}

Keywords: Educational Rights, Religious Education Service, Students of Indigenous of Nuaulu.

\section{Introduction}

Developed countries are usually influenced by advanced education, because in order to get a prosperity in life, education factor is the main pion. With education, it is hoped that there will be changes in the life of people and community towards a more prosperous direction. The development of education will have an impact on the development of human resources, and excellent human resources will have an impact on the developing of a country. The country becomes strong and developed depending on how education is carried out in the country. In Indonesia, one of the noble goals of the government is to educate the life of the nation, so it is not surprising that education is categorized as one of the constitutional rights of every citizen. As a part of human rights owned by someone, government is obliged to provide education to its people. In order to implement the mandate of the constitution, an instrument of regulation related to education was made, one of which is Law Number 20 Year 2003 concerning the National Education System (Law Number 20 Year 2003). This law confirms that every citizen has the same right to get education. In addition, education is held in a democratic, just and non-discrimination principle by upholding human rights, religious values, cultural values, and national pluralism. 
With the affirmation of this law and other affirmations in this law, it can be concluded that Law Number 20 Year 2003 has accommodated human rights values in it.

It was also stated that members of the community who try to develop their potential through the learning process available at certain way, levels, and types of education or what we called students, in each education unit were entitled to receive education in accordance with the religion they professed which is taught by the same religion educators. This mandate is also part of the protection of human rights. However, in the implementation itself, the form of providing education of religion which is similar with students' religion has not been fully implemented yet. This has led to curiosity, how this law has been passed since 2003 but the implementation of religion education has not been carried out as it should. Another curiosity is to whom the country is negligent to do its obligation to protect one's rights. This can be found to those students who have Indigenous Religion in God Almighty, or what we are familiar with Penghayat Kepercayaan (some refer to it as native religion, tribal religion, local religion, etc.). Up to this time, students who have Indigenous Religion in God Almighty generally experience adverse treatments related to religion education. They do not get education of religion in accordance with their religion. To complete the requirement of the learning, they have to attend religion class that different with their religion, even though they do not understand what they are learning but for the sake of grading and a piece of paper of diploma, they inevitably have to do it.

What was stated above is a problem experienced by the believers of tribe religion or indigenous religion in general all over Indonesia and this is also experienced by one of the tribe in Maluku, especially in Central Maluku Regency, known by the name of the Nuaulu tribe (read: Naulu). The Nuaulu tribe is one of the tribes in the area who still practice their original beliefs which they professed long before modern religions come to Indonesia. Their beliefs make difficulties for them in administration related to the religion column on the National Identity Card (KTP) and Family Card (KK) which must not be left blank. Therefore, they inevitably have to write religion according to one of the six official religions in Indonesia. The use of Family Card (KK) is one of the requirements for enrolling their children in schools. Besides, the data in Family card has been used also for school data. Hence, because of the data, the school requires them to attend religion class which is related with what is written. To cope with the problem of discrimination in religioneducation, the government issued a regulation under Minister of Education and Culture Number 27 Year 2016 concerning Education Services for Believers to God Almighty in each Education Units (Permendikbud Number 27 Year 2016). After three years of the issued date, another curiosity arises, whether or not this law has been implemented especially for tribe religion believers. Therefore, this paper would like to examine more specifically on the Nuaulu tribe believers, whether the religion education service for Nuaulu tribe believers in the Central Maluku District of Maluku Province has been carried out and what are the obstacles in the implementation. 


\section{Literature Review}

\section{a) Education}

The most comprehensive explanations on the right to education can be seen in the Convention on the Rights of the Child Article 28, including:

1. States Parties recognize the right of the child to education, and with a view to achieving this right progressively and on the basis of equal opportunity, they shall, in particular:

(a) Make primary education compulsory and available free to all;

(b) Encourage the development of different forms of secondary education, including general and vocational education, make them available and accessible to every child, and take appropriate measures such as the introduction of free education and offering financial assistance in case of need;

(c) Make higher education accessible to all on the basis of capacity by every appropriate means;

(d) Make educational and vocational information and guidance available and accessible to all children;

(e) Take measures to encourage regular attendance at schools and the reduction of drop-out rates.

2. States Parties shall take all appropriate measures to ensure that school discipline is administered in a manner consistent with the child's human dignity and in conformity with the present Convention.

3. States Parties shall promote and encourage international cooperation in matters relating to education, in particular with a view to contributing to the elimination of ignorance and illiteracy throughout the world and facilitating access to scientific and technical knowledge and modern teaching methods. In this regard, particular account shall be taken of the needs of developing countries.

In Indonesia, one of the objectives of the nation as stipulated in the Preamble to the 1945 Constitution of the Republic of Indonesia (UUD 1945) is to educate the nation, which is further stated in Article 31 stated in paragraph (1) that every citizen has the right to education. This right is reaffirmed in the amendments of the UUD 1945 Year 2000, namely in Article 28c paragraph (1) which reads: "Everyone has the right to develop themselves by fulfilling their basic needs, the rights to get education and to benefit from science and technology, arts and culture, in order to improve the quality of life and for the welfare of mankind". The UUD 1945 mandates the government to strive for and implement a national education system that enhances faith to the Almighty God and noble character in order to educate the nation that is regulated by law. Therefore the formation of Law Number 20 Year 2003 replaces Law Number 2 Year 1989 concerning the National Education System which is deemed inadequate and needs to be replaced and refined to conform to the mandate of the UUD 1945.

In general, the reform movement in Indonesia demands the implementation of democracy, decentralization, justice and upholding human rights in the daily life of the nation. In relation to education, these principles will have a fundamental impact on the content, processes and management of the education system. In addition, science and technology have developed rapidly 
and brought new demands in all aspects of life, including in the education system. The demand is related with the renewal of the education system, including curriculum renewal, that is curriculum diversification that serve students need and the diverse potentials of its region, diversification of types of education carried out professionally, the standardize of graduate competency that apply everywhere both national and regional adjust to local conditions; the forming of standard for teacher qualification in accordance with the demands of professional implementation of the task; preparation of education funding standards for each education unit in accordance with the principles of equity and justice; implementation of school-based education management and university autonomy; and organizing education with an open and multi-meaning system. The renewal of the education system also includes the elimination of discrimination between government-managed education and community-managed education, as well as the distinction between religious education and general education (In the General Explanation of Law Number 20 Year 2003).

With the principles of education as mandated by this Law in Article 4, which are:

(1) Education is held democratically and fairly without any discrimination by upholding human rights, religious values, cultural values, and national pluralism.

(2) Education is organized as a systemic unit with an open and multi-meaning system.

(3) Education is organized as a process of civilizing and empowering students that happens for a lifetime.

(4) Education is organized by giving examples, building will and motivation, and developing students' creativity in the learning process.

(5) Education is organized by developing a culture of reading, writing and numeracy for all citizens.

(6) Education is organized by empowering all components of society by participating in the implementation and controlling the quality of educational services.

Anyone who has the right to participate in education are explained further in Article 5 of the laws :

(1) Every citizen has the same right to obtain quality education.

(2) Citizens who have physical, emotional, mental, intellectual, and/or social disabilities are entitled to special education.

(3) Citizens in remote or undeveloped areas and remote indigenous peoples are entitled to receive special service of education.

(4) Citizens who have special intelligence and talent are entitled to special education.

(5) Every citizen has the right to have the opportunity to improve their education throughout their life.

The article above shows its emphasis on citizens, because it explicitly states that all citizens can get a good quality of education, without discrimination. Then in Article 10, it is stated that the Government and Local Governments have the right to direct, guide, assist, and supervise the implementation of education in accordance with applicable laws and regulations. Furthermore, Article 11 paragraph states that (1) the Government and Regional Governments must provide services and facilities, and ensure the quality of education for every citizen without discrimination, and paragraph (2) the Government and Regional Governments must guarantee the availability of funds for the implementation of education for every citizen from aged seven to fifteen. Based on the articles mentioned relating to human rights, Article 5 mandates the rights of citizens while Article 10 concern on government rights and Article 11 concern on citizens obligations. 


\section{b) Custom/Adat Community}

The implementation of legal pluralism directly is also a government's effort on how government is able to respect the existence of the rights of adat peoples in making policies. Basically, adat community are not people who refuse development. They needs to get differenttreatment realizing that there is a different understanding of the law which has a magicalreligious nuance. The principles of informed consent or priority for them to get the widest possible accessshould be included in every rule of law that will related with them. The existence of adat peoples and their law in Indonesia can at least be seen from two arguments, which are [1]:

\section{Social Arguments}

Adat law is still relevant to be implemented in Indonesia. Adat law is a law that comes from the original culture of Indonesian. It grows and develops with the values that live within society. Society thinks and acts according to the values that distinguishes them from Western culture. Indonesian society is also a pluralistic society which consists of various ethnic groups which according to Theodorson is interpreted as follows: "cultural heterogeneity, with ethnicity and minority order groups maintaining their identity within a society".

The plural form of society shows a heterogeneous form of culture which in this case characterizes certain identities within the community. The sociological form of plural adat law community shows conformity and harmony. This can be seen in various conflicts that occur in the community in which the community tends to use their law to resolve disputes that occur because it is related with the values and culture of the nation.

\section{Juridical Arguments}

Recognition of the normative customary/adatlaw is more specifically regulated since the Dutch East Indies period in Article 131 paragraph (2) sub b Indische Staatsregering which states, the customary/ law applies for the native class.Nowadays, the recognition of the validity of this law is constitutionally stated in Article 18B paragraph (2) of the UUD 1945 which states:

"The state recognizes and respects the customary law community units along with their traditional rights as long as it still exist and in accordance with the development of the community and the principles of the Republic of Indonesia which are regulated in the law".

Juridical recognition of the validity of indigenous peoples in the Second Amendment of the UUD 1945 makes the existence of customary law in Indonesia even stronger, because it has been claimed as the constitutional rights of Indonesian citizens owned by indigenous peoples. The implementation of customary law in this way does not become ambivalent, that is, in this case acknowledging, but the recognition is clearly limited.

In addition to the term indigenous peoples, we also hear the term customary law community. All customary law community are indigenous or adat peoples, but not all indigenous peoples are customary law community. Characteristics of customary law community include some elements owned by indigenous peoples as been mentioned above and also some additional elements such as the existence of traditional laws that apply and the existence of institutions and legal instruments that enforce the rule of law. 


\section{c) Belief And Indigenous Religion}

The government, through the Ministry of Home Affairs, has issued a Regulation Number 33 Year 2012 concerning Guidelines for Registration of Community Organizations within the Ministry of Home Affairs and Regional Governments. In this regulation, religion and belief are distinguished, but are still treated equally. Organizations that are formed on the basis of religion and belief are declared as community organizations. To be registered, this organization in the name of religion and beliefs are required to complete documents which include recommendations. If the organization is based on religion, then a recommendation must come from the Ministry of Religion (Article 9 letter s). Meanwhile, organization in the name of belief is required to have a recommendation from the ministry and department that is in charge of cultural affairs (Article 9 letter $\mathrm{t}$ ). With this recommendation, belief has been manifested as part of culture rather than religion from the beginning.

Then the stipulation of regulation under the Minister of Education and Culture of the Republic of Indonesia Number 77 Year 2013 about Helping Guidelines for Belief institution and Customary Institutions, which are guidelines for "help" religion and customary institutions in region and province/city/regency. The word Help as a language of policy or bureaucracy that was popular since the era of New Period, especially related to the issue of belief groups and adat, is often understood as an effort (the government to) change (belief groups and customs) from not/not good to be good or better. That what was suggested from the term of "help" in Permendikbud: "(Article 1) The formation of a Belief Institutions and Customary Institutions is a process, method, effort, action, and activity carried out efficiently and effectively to obtain better results." For believers of ancestral religions, the word "help" is actually very familiar. Historically, since their beliefs were categorized as "culture," they have been treated as "helping objects." As quoted from Constitutional court Decision Number 140/PUU-VII/2009 related to the response of the Association of Believers (HPK), they feel that they are treated as coaching/helping objects where "The government is trying to influence the mysticism (which is considered "unhealthy") towards a healthy view towards God," or in other word they are encouraged to choose one of the official religions [2]. Basically, not all indigenous people in Indonesia belongs to official religions such as Islam, Protestant, Catholic, Hinduism, Buddhism, or Khong $\mathrm{Hu} \mathrm{Cu}$. We can still find out that there are many indigenous peoples who remain faithful to their original beliefs which have been passed down from their ancestors, long before modern religions entered Indonesia.

According to the Joint Regulation of the Minister of Home Affairs and the Minister of Culture and Tourism Number 43 Year 2009 Number 41 Year 2009 concerning Guidelines of Services for Believers of the Almighty God, that what is meant by belief in God Almighty is a statement and implementation of personal relations with God Almighty that is based on beliefs that are manifested in the attitude of devotion and worship of God and the practice of virtue that the knowledge come from the local wisdom of the Indonesian. While the believers of God Almighty, is everyone who recognizes and believes the values of living faith of God Almighty. Then there is also the organization called the Organization of Penghayat Kepercayaan, that is registered under The Ministry of Home Affairs and acknowledged by the Ministry of Culture and Tourism. This organization then is being called as Majelis Luhur Kepercayaan Terhadap Tuhan Yang Maha Esa Indonesia (MLKI). 


\section{Method}

The method used in this research is empirical juridical which means the primer data is collected through the work of law in society. This approach has been used in order to get a clarification and correlationlink of the problems found [3]. The location of the research is Central Maluku Regency. The types and sources of data used are:

a) Primary data is data obtained or collected by researchers in the field directly from the data source by means of observation, interviews and discussions with the interviewees.

b) Secondary data is data obtained or collected by researchers from various existing sources. Secondary data can be obtained from various sources such as books, reports, laws and regulations, journals, and others.

c) Tertiary data is data taken by internet media or websites.

Data analysis used in this paper is qualitative analysis. Qualitative analysis is a way of describing data in a quality and comprehensive manner, which is taken from literature studies as well as observations and interviews.

\section{Result and Discussion}

The results of the study show that followers of the Nualu indigenous people since the enactment of the education law by Law Number 20 Year 2003, until 2019 have not received religious education in schools starting from elementary to high school and college levels according to their religion.

\section{a) Religious Education Services In Indonesia}

As explained earlier that one of the mandates of the UUD 1945 is that all citizens are entitled to get a good education. This is more explicitly stated in Article 26 paragraph (1) of the 1945 Constitution that those who are Indonesian citizens are native Indonesian people and other nationalities who have been ratified by law as citizens. Furthermore, it is clearly regulated in Law Number 12 Year 2006 concerning Citizenship of the Republic of Indonesia. Citizens according to this law are citizens of a country determined by regulations. Indonesian citizens consist of:

i. Every person who before this law has become Indonesian citizen;

ii. Children born from legal marriages of Indonesian citizens fathers and mothers;

iii. Children born from legal marriages of Indonesian citizens fathers and mothers from another nationality;

iv. Children born from legal marriages of foreign nationals fathers and mothers;

v. Children born from legal marriages of Indonesian citizens and non-citizenship fathers;

vi. A child born from a legal marriage from an Indonesian citizen, before 300 days his father passed away;

vii. Children born outside of legal marriages from Indonesian mother;

viii. Children born outside the legal marriages of foreign national mothers but being recognized by Indonesian fathers;

ix. Children born in Indonesia whose citizenship status of mother and father is still unclear. 
Based on all the descriptions above, both those related to customary law communities and citizens, it is clear that the customary law communities that have existed since ancient times in Indonesia are Indonesian citizens. Thus, in the relationship between citizens and the country itself, citizens have obligations to their country and vice versa, citizens have rights that must be granted and protected by the country. The right to obtain good quality of education is one of the rights that must be granted and protected by the nation to indigenous peoples, in this case the author is referring to the right to obtain the suitable religious education. In Law Number 20 Year 2003 Article 12 letter a, it is stressed that every student in each education unit is entitled to receive religion education in accordance with the religion he/she professes and the religious education itself should be taught by educators of the same religion. The students in this context referred to members of the community who are trying to develop their potential through a learning process that is available at certain levels, ways and types of education.

If we follow the development of customary law community in Indonesia with this ancestral belief, then there are many discrimination treatment they have felt. In relation to population and civil registration, to complete their data that cannot be included because they have the special tribe religion, they must choose one of the six religions mentioned above, just because of the reason that the religion column should not be left blank. This bring some impacts in many aspects, one of which is education. Because the school registration form include religion statement, they inevitably have to write one of the religions to complete the file, as well as complete the family file such as a Family card which includes the religion that they chose but not adhered to by them. Beside, in religious education, they are required (more coercive) to attend certain religious subjects which belongs to the majority of religions in their schools. The problem that arises is that Article 12 letter a is not implemented as it should be. From this article, there are two concepts contained which are (1) the right to obtain religious education in accordance with the religion it professes; and (2) taught by educators of the same religion. This paragraph is a further elaboration of the mandate of the UUD 1945 which requires that every citizen has the right to education, including religious education. Thus it is clear that there has been a violation of the constitutional rights for the followers of tribal religion because it is stated that the students should not receive religious education that is not in accordance with their religion and be taught by educators which doesn't have the same religion.

As previously stated that the Constitutional Court of the Republic of Indonesia has issued Decision Number 9/PUU-XIV/2016, then this regulation gives a fresh air for the followers of Indigenous Religion have struggled for a long time and have waited for their beliefto be recognized. Whereas in the world of education, the Minister of Education, Anies Baswedan, at the same time has issued the Regulation under Minister of Education and Culture Number 27 Year 2016 concerning Education Services for Followers of God in eachEducational Unit. In this regulation, it is stated that the Religion Education Service is a religious education given for the students of nondenominational faith. Furthermore, the education of belief to Almighty God is called Religious Education that is learning about God. What is meant by students of Indigenous Religion or Penghayat Kepercayaan are students in formal education at the level of primary and secondary education andsimilar level of education who declare themselves as the Believers of Indigenous Religion. These believers, here in after are also mentioned as any person who recognizes and believes the values of faith in Almighty God. Beliefin Almighty God is a statement and implementation of a personal relationship with God based on beliefs that are manifested by the 
attitude and worship of God and the practice of virtue whose teachings originate from the local wisdom of Indonesian people. The students are encouraged to fulfill religious education by following the provisions of the legislation governing the curriculum. The content of religious education must has fulfilled some competencies such as core competencies and basic competencies, syllabus, lesson plans, textbooks, and educators. The core competencies and basic competencies are compiled by MLKI and submitted to the Ministry to be declared.

Based on the empirical data and with the issuance of Minister of Culture and Ministerial Regulations, it has opened the veil of access to religious education for students from tribal language, one of which is in Central Java Province, which is one of the provinces with the largest number of believers of local tribe religion in Indonesia. From the data at the Ministry of Education and Culture [4], out of 178 thousand residents, nearly half of them live in the Central Java region. In the implementation, the believers of this tribal religion in Central Java can be used as a barometer for other area in Indonesia, because based on an online search, it can be seen that the development of religious education services in Indonesia has been implemented based on the synergy of local governments, schools, and the believers, although initially the school still did not accept the existence of this education but over time, it can be accepted. One of them, as told by Samino [5], a graduate of an art school whose daily activities are in his art and craft, was appointed as a teacher of religious education services by MLKI Cilacap. In addition there are also Tarminto and Surani [6] who are teachers of religion and etiquette in Semarang Regency, who are appointed by the association and also the materials and assessments used. The instructors do not get incentives or salaries from the Department of Education because those are non-permanent teachers. Religious education services are taught in the level of Primary School (SD), Junior High School (SMP), and High School (SMA). In addition, in 2018, the first time a religion tribeclass in Cilacap, Central Java had taken the National Standard School Examination (USBN) on behalf of Adelia Permatasari [7].

\section{b) Religious Educational Service For Indigenous Raligion Of Nuaulu}

In Maluku Islands, there are local beliefs which can be found on the islands of Buru, Elat, Wetar, Yamdena, Tanimbar, Kei and so on, which are often referred to as Hindu (local Hindu). Their Hindu is more into cultural and tradition and not Hindu like in Bali. This kind of Hindu which is more into culture exists only in Maluku packed with social and tradition backgrounds in Maluku. With their respective names for God such as Upuku Anahatana, Upu Ila Kahuresi, Opolastala, Duad, Upu Lera, Jar Duai [8]. Thesenamesindicate that they believe in the existence of God Almighty which they describe the Deity according to their view, therefore they can be considered also as believers. Just like other faith-bearing communities in Indonesia, faith-bearing communities in Maluku such as in Buru Island and Seram Island are stigmatized as irreligious people, infidels, animists, related to black magic and so on. This mindset that is labeled to them either arises from less knowledge that we have or whether arises from unclearly understanding. The representation of the treatment for such a belief in Indonesia is an inseparable part of what is experienced by the followers of the faith in Maluku. In order to maintain their existence then in citizens registration file, they must choose the religion that appears so that some of them choose the religion of Islam, Christians, and Hindus as a formal requirement that they have a religion, but 
in reality they still carry out their original beliefs. One of them is the Nuaulu tribe located on the island of Seram.

Nuaulu is derived from the word Nua which means the name of a river, Ulu means the head of the river (upstream). Therefore, Nuaulu can be interpreted as those who live the headwaters of the Nua river in the south-central part of Seram Island. From Molluccans, Seram Island is called Nusa Ina (Mother Island). In addition to being larger than the other islands in the Maluku Archipelago which is $18,625 \mathrm{~km}^{2}$, in the cosmology of the Moluccans, Seram Island is believed to be the origin of all Moluccans who descended from the ancient kingdom of Nunusaku, and spread to small islands nearby. Nuaulu population reaches 3000 people. They are spread in 9 locations namely Nua Nea, Bonara, Latane (Old Village), Hahuwalan, Simalouw, Rohua, Rohua Waemanesi, Hatuhenu (Nusatauwe) and Tawane-Waene. The people are classified into 12 clans or family name which are Matoke, Kamama, Sounawe Aepura, Sounawe Aenaka-hata, Sopalani, Perissa, Hury, Nahatue, Soumory, Leipary, Rumalait, Pia. They don't have a specific name that is given to describe their belief system they have. When discussing to another community, the Nuaulu people call their religion the Nuaulu religion or the religion of Nuaulu tribe [8]. The Nuaulu people refers God as Upuku Anahatana or Anahatana as the highest source and owner of life, creator of human being, plant, animal, land, as an inseparable deity. For the Nuaulu, the universe is guarded by Upu as imediator of Upuku Anahatana namely Nue Nosite (the guard of the sea), Wesia Upue (the guard of the land), Sionoi Aha (the guard of the air), and Seite Upue (the guard of the forest or garden). These four forces have the power to grant the wishes of the Nuaulu people, and bring disaster. There is also Rae Upu, an ancestor who has passed away and can communicate with Nuaulu people if needed. Each clan in the Nuaulu community has a different Rae Upu and is personified in various symbols (totems) [8]. In addition, there are also some Nuaulu who have converted to Islam and Christianity whether Catholic or Protestant.

Their believe and respect for Upuku Anahatana or Anahatana occupies the highest position of things that are considered sacred, making Nuaulu people in their daily lives, cannot be separated from what is considered appropriate to do by considering things that are sacred as a moral foundation. The cosmology of the Nuaulu community is based on a strong belief and fundamental view that nature and its contents have a soul. The elements of the cosmos such as mountains, forests, rivers, seas and so on have soul elements. This natural soul or the cosmos soul is binding, unite with the elements of the universe. When interacting with the wider community, Nuaulu people always prioritize peace. Their principle is that as long as they do good, there will be no bad things happen. For Nuaulu, the ethics are forbidden to steal, greet others with inappropriate calls, and various other customary rules. They see the nature and the forest as partners, as part of their lives, so it needs to be cared properly and seriously. Destroying the nature is the same as destroying yourself. The spiritual life of the Nuaulu also acknowledge the balance of life in the world. In human soul, there are two main characters, which are the nature of good and the nature of evil. They believe that every good deed will get a good reward in the form of supuyake, while bad deeds will get a bad reward or a sin called monne. Bad deeds can impact in disruption of the cosmos resulting the emergence of various disasters. According to their understanding, the cosmos can only be renewed by repenting through prayer rituals which are performed together solemnly [8].

Thus a glimpse of the beliefs of the Nuaulu. It has been mentioned before that they must also get some discrimination treatment in population administration part especially in the religion 
column for describing their identity. After the Constitutional Court Decision Number 97/PUU$\mathrm{XIV} / 2016$, there has been no change in their KTP religion column. In conversations with several people in Nua Nea, one of the places inhabited by the Nuaulu tribe, one of them is the Customary Chief (King) of Nua Nea (dated May 5, 2019), it is shown that they only just found out about the decision so that they have not updated their identity card. There are also sources that say that there are already two Nuaulu people livednear Nua Nea, who have changed their ID. In July 2019, a cultural meeting was held by three tribes in Seram, the Naulu, Huaulu and Yalhata tribes initiated by the Central Maluku Pamahanunusa Christian Education Foundation together with the Maluku Provincial Education and Culture Department team, Central Maluku Deputy, Central Maluku Population and Civil Registry Office with an agreement to put the religion of these tribes in the religion column on their ID Cards [9]. The author has tried to confirm this information with the Population and Civil Registry Office for Central Maluku Regency on August 1, 2019, apparently there was no ID card issued for a religion change. Because they experienced some problems in the system, the choice of Tribe name did not appear when clicked on online data for religion of Nuaulu community.

Moreover, about religion education for Nuaulu students who should receive education services related to their belief, just like other faith followers in Indonesia, they must also follow religion education program as stated in the family cardwhen they fill in the school admission form. Then they must attend those religion studies according to the data, which is not in accordance with their beliefs. This certainly makes them have to adjust to something they do not understand in order to get grades on reports or a piece of paper of diploma. Some even choose to drop the class, because they thought it was not their religion, that makes them fail the class (in order to graduate, the students had to pass all the class). One of the followers of the Nuaulu faith who now studies at the Faculty of Law at Pattimura University, Pateki Sounawe (interview, dated August 14, 2019), tells the story of his religious education from Primary to high school is Islam and in universities is Protestant, while on his ID card, his name is written in Hinduism. How sad is the experience only in order to get recognition as part of Indonesian. There are also those who have worked, become Civil Servants with religion in ID Cards that are different from the real religion. After the meeting of the three tribes mentioned above, there is a fresh breeze that is very much expected by the Nuaulu community in addition to administration data as well as the problem of getting a proper religion education. With the start of the new school year, the author tries to find out the issue of religion education in Central Maluku Regency, but apparently it has not been applied yet. This is perfectly natural because the system and the management of education is not easy. Education management as been stated in the Minister of National Education Regulation of the Republic of Indonesia Number 19 Year 2007 concerning Education Management Standards by the Elementary and Secondary Education Unit, which contains the following matters:

A. Program Planning

B. Implementation of the Work Plan, consisting of:

1. School/Madrasa Guidelines

2. School/Madrasah Organization Structure

3. Implementation of School/Madrasah Activities

4. Student Affairs

5. Curriculum and Learning Activities

6. Educators and Educational Staffs 
7. Facilities and Infrastructure

8. Finance and Budgeting

9. School/Madrasah Culture and Environment

C. Monitoring and Evaluation

D. School/Madrasah Leadership

E. Management Information Systems

Based on the regulation that has been mentioned, there are a number of points that are actually a problem related to the implementation of Nuaulu Religion education services, including:

\section{Curriculum}

Education Unit Level Curriculum or KTSP (even currently in Curriculum 2013) compiled by Schools/Madrasah following Graduates Competency Standards, Content Standards, and implementing regulations. Each teacher is responsible for compiling the syllabus for each subject in accordance with the Content Standards, Graduates Competency Standards, and KTSP Compilation Guidelines. Preparation of KTSP at elementary and junior high levels is coordinated, supervised, and facilitated by the District/City Education Office while Inclusive school for Primary, Junior High and Senior High or Vocational School, are being arranged by the Provincial Education and Cultural Department. While for the preparation of KTSP for Religion Education at the elementary and junior high school levels, they are coordinated, supervised, and facilitated by the District/City Department of Religion Office, while for Inclusive school for Primary, Junior High and Senior High or Vocational School by the Regional Office of the Ministry of Religion. This shows that in making the school curriculum, there are some conditions that must be considered, and the teacher is responsible for each lesson. Another problem that arises is about the availability of teachers who compiled the syllabus and the availability of other media supported the learning process.

However, at this point, there is an opportunity for the curriculum to be made by considering the potential characteristics of the local and cultural community of the locals, thereby opening up space for the arrangement of a curriculum for the specific religion education by schools that are close to the Nuaulu tribal settlement. And because this is religion education, the school can coordinate with the Department of Religion in the province o Regency.It should be taken into account that according to Law Number 20 Year 2003, the curriculum is prepared in accordance with the level of education within the framework of the Republic of Indonesia by considering: a. increasing of faith; $b$. increasing of noble character; $c$. increasing of the potential, intelligence, and interests of students; d. diversity of regional and environmental potentials; e. regional and national development demands; f. demands of the world of work; g. the development of science, technology and art; h. religion; i. the dynamics of global development; and j. national unity and national values. Thus, there is no reason for a curriculum for the specific religion education cannot be made. In line with that, Regulation of the Minister of Education and Culture Number 27 Year 2016 also stated that the content of specific religion education must have core and basic competencies, syllabus, lesson plans, textbooks, and Educators. Then to facilitate the school, it was further arranged that the core competencies and basic competencies be prepared by the MLKI and submitted to the Ministry to be arranged. 


\section{Educators}

According to Law Number 20 Year 2003, educators are professionals who are tasked with planning and implementing the learning process, assessing learning outcomes, conducting mentoring and training, and conducting research and community service, especially for educators at tertiary institutions. Educators must have a minimum qualification and certification in accordance with the level of teaching, physically and mentally healthy, and have the ability to reach national education goals. Educators for formal education at the level of early childhood education, basic education, secondary education, and higher education are developed from accredited tertiary institutions. Religion education must be taught by the educatior who hold same religion.

Related to this point, there are several problems happens: a. there are no educators who have met the minimum qualification requirements and certifications related to religion education for the Nuaulu tribe; $b$. there are no higher education institutions that have study about this religion education in Maluku Province. Furthermore, in the Minister of Education and Culture Regulation Number 27 Year 2016, it is stated that educators for specific religion are educational staff who are qualified as teachers, tutors and other designations in accordance with their specificities and participate in organizing specific religion education to God. As a derivative of Law Number 20 Year 2003, it seems that the clause in the Ministerial Regulation is not complete, the qualification indicator referred here, if interpreted, refers to professional educators who have graduated from teacher training at tertiary institutions. The government, in this case the Ministry of Education and Culture, has issued Letter Number 03/D/SE/PO/2017 concerning the National Standard of School Exams for specific religion followers, there is a clause that reads that if there are no teachers competent in teaching the subject then the test is carried out by the senior or the leader of the specific religion appointed. This letter usually is a form of a discretion in the implementation of governmental functions, usually come out because there is a choice in the regulations, there is no regulation, it is incomplete or unclear, and/or there is a problem of government stagnation. Regulations related to specific religion education services are incomplete or unclear, so it can be concluded that the presence of this letter is a form of discretion to the problem. So that in the future it is expected that there are more strict rules on this issue.

\section{Infrastructure Facilities}

It is related to the completeness of the facilities owned by the school, for example, a study room for specific religion education students, as well as books in libraries related to the subject.

\section{Finance and Budgetting}

This is about the availability of learning tools, teachers for specific religion teachers, infrastructure that will have an impact on the budget. Nuaulu tribal believers have the same right to obtain quality education without discrimination, as stated in international instruments such as the Convention on the Rights of the Child Article and the International Convention Against Discrimination in Education 1960, as well as national legal instruments containing the principles 
of implementation education,stated that education should be carried out democratically and fairly and is not discriminatory and upholding human rights, religious values, cultural values, and national pluralism. Then this principle applies to the education of all Indonesian people, thus this also applies to students with Nuaulu ethnic beliefs who must get education in accordance with their beliefs. To overcome the problems of the community related to their belief, then with other principles that education is carried out by empowering all components of society through participation in the management and quality control of educational services, the Education Office in the District and Province can hold the Nuaulu tribe community and schools to solve educational problems trust. The role of the government is very important in solving education problems because it is based on the mandate of Law Number 20 Year 2003 so that the Government and Regional Governments have the right to direct, guide, assist, and supervise the implementation of education in accordance with applicable laws and regulations. In addition, it is obligatory to provide services and facilities, as well as guarantee the quality of education for every citizen without discrimination, and must guarantee the availability of funds for the implementation of education for every citizen aged seven to fifteen years old.

\section{Conclusion}

Legal instruments related to Education services on belief is Law Number 20 Year 2003 and Culture Number 27 Year 2016, mandates to provide religion education in accordance with the religion of the students. This also applies to learners who belongs to indigenous religion. However, in reality, these regulations have not been implemented equally in all regions in Indonesia. This problem is experienced by students who believe in Nuaulu tribal belief in Maluku, where they have not received Education services on belief from elementary to secondary level. The difficulties are the elements found in the education management standards that have not been fulfilled yet, such as curriculum, educators, and infrastructure facilities that are not yet available as well as finance and budget. All of these obstacles are inseparable parts because they are a systematic system. Therefore, to cope with this problem, it is hoped that there will be a synergy from all the stakeholders such as the local government specifically the education department, schools, and communities that support the Penghayat kepercayaan of Nuaulu tribe.

\section{References}

[1] Rikardo Simarmata, Pengakuan Hukum Terhadap Masyarakat Adat di Indonesia.: UNDP, 2006.

[2] Samsul Maarif, Pasang Surut Rekognisi Agama Leluhur Dalam Politik Agama di Indonesia. Yogyakarta: CRCS (Center for Religious and Cross-cultural Studies) Progam Studi Agama dan Lintas Budaya Sekolah Pascasarjana Lintas Disiplin, Universitas Gadjah Mada, 2018.

[3] Soerjono Soekanto, Penelitian Hukum Normatif Suatu Tinjauan Singkat. Jakarta: Rajawali Pers, 2006. 
[4] Fariz Fardianto. (2019, June) IDN Times Jateng. [Online]. https://jateng.idntimes.com/news/jateng/fariz-fardianto/prodi-kepercayaan-kepada-tuhan-yme-jadiwarna-baru-dunia-pendidikan/full

[5] Muhamad Ridlo. (2017, November) Liputan $6 . \quad$ [Online]. https://www.liputan6.com/regional/read/3157607/cara-siswa-penghayat-kepercayaan-di-cilacapbelajaragama?related=dable\&utm_expid=.9Z4i5ypGQeGiS7w9arwTvQ.1\&utm_referrer=https $\% 3 \mathrm{~A} \% 2 \mathrm{~F} \% 2$ Fwww.liputan6.com\%2Fregional\%2Fread\%2F3157607\%2Fcara-siswa-penghayat-kepe

[6] Khoirul Muzakki. (2018, November) Tribun Jateng. [Online]. https://jateng.tribunnews.com/2018/11/19/belum-ada-sarjana-aliran-kepercayaan-dua-guru-dikabupaten-semarang-ajarkan-pendidikan-kepercayaan

[7] Muhamad Ridlo. (2018, March) Liputan $6 . \quad$ [Online]. https://www.liputan6.com/regional/read/3417109/adelia-permatasari-siswa-penghayat-kepercayaancilacap-pertama-ikutiusbn?related=dable\&utm_expid=.9Z4i5ypGQeGiS7w9arwTvQ.1\&utm_referrer $=$ https $\% 3 \mathrm{~A} \% 2 \mathrm{~F} \% 2 \mathrm{~F}$ www.google.com $\% 2 \mathrm{~F}$

[8] M Azis Tunny, Beta Agama Noaulu. Yogyakarta: Smart Writing, 2013.

[9] Tiara Melinda. (2019, July) [Online]. https:/www.gatra.com/detail/news/430621/millennials/akhirnya-agama-tiga-suku-asli-di-malukudiakui 